\title{
Vaginal Discharge in the Prostitutes of the Group Yèrêlon of Bobo-Dioulasso: Epidemiological, Clinical and Etiological Aspects
}

\author{
Bambara Moussa*, Ouedraogo Jean Louis, Mansour Niang, Diallo Abdoul Azize, Zampaligre Idrissa \\ Gynécologue, Bobo-Dioulasso, Burkina Faso \\ Email: *mousbambara@yahoo.fr
}

How to cite this paper: Moussa, B., Louis, O.J., Niang, M., Azize, D.A. and Idrissa, Z. (2017) Vaginal Discharge in the Prostitutes of the Group Yèrêlon of Bobo-Dioulasso: Epidemiological, Clinical and Etiological Aspects. Open Journal of Obstetrics and Gynecology, 7, 871-879.

https://doi.org/10.4236/ojog.2017.78088

Received: April 9, 2017

Accepted: August 6, 2017

Published: August 9, 2017

Copyright $\odot 2017$ by authors and Scientific Research Publishing Inc. This work is licensed under the Creative Commons Attribution International License (CC BY 4.0).

http://creativecommons.org/licenses/by/4.0/

\section{Open Access}

\begin{abstract}
The authors report a cross-sectional descriptive study over 6 years, from December $8^{\text {th }}, 2003$ to October $27^{\text {th }}, 2009$, involving 911 women involved in the sex trade within the Yèrêlon group in Bobo-Dioulasso. Objectives: To describe the epidemiological, clinical and etiological aspects of vaginal discharge in women in the Yèrêlon group of the city Bobo-Dioulasso. Results: Frequency of vaginal discharge was $48.89 \%$. The mean age was 28.4 years with extremes of 16 and 54 years. Single, divorced and widowed women accounted for $78.8 \%$ of the study population. Women who never attended school and those with primary education accounted for $74.3 \%$ of the study population. HIV serology was positive in $38.4 \%$ of cases. The main symptoms were genital itching, dyspareunia and urinary signs. The main germs identified in the laboratory were Candida albicans, Trichomonas vaginalis and Gardenerella vaginalis. Conclusion: vaginal discharge was found in $48.89 \%$ of women in the Yèrêlon group of Bobo-Dioulasso. The clinical study of the discharge and the laboratory results allowed a diagnosis and a better management of the leucorrhea in the group Yèrêlon.
\end{abstract}

\section{Keywords}

Leucorrhea, Sex Trade, Candida albicans, Trichomonas vaginalis, Gardenerella vaginalis

\section{Introduction}

Leucorrhea is non-bloody female genital discharge. It can be pathological, in this case translating a genital infection. If the vaginal discharge is usually mild, it may 
have an impact on the couple's sexual and emotional life, and also could have dramatic consequence, such as ectopic pregnancy or infertility [1].

Like other sexually transmitted infections (STIs), vaginal discharge promotes sexual transmission of the human immunodeficiency virus [2].

Sex workers have multiple partners, and this behavior promotes the spread of HIV and STIs. We undertook this study on the vaginal discharge in women of the Yèrêlon group in order to study the epidemiological, clinical and etiological aspects.

\section{Materials and Methods}

A cross-sectional, descriptive study over a 6 years period, from December 8 , 2003 to October 27, 2009 was carried out, in Bobo-Dioulasso, as part of a research project called Yèrêlon on the prevention and management of sexually transmitted infections and the human immunodeficiency virus in professional sex workers and women infected with HIV from the Associations of People Living with HIV.

1) Inclusion and non-inclusion criteria

Inclusion criteria

- be a woman aged 18 years and over;

- be sexually active;

- agree to participate in HIV testing and testing.

Non-inclusion criteria

- to be pregnant;

- refusal of screening Of HIV.

\section{2) Conduct of the study}

The visits included conducting a behavioral questionnaire, an InformationEducation-Communication (IEC) session, counseling for HIV testing, a medical examination with genital specimens (vaginal specimen culture and sensitivity) and blood tests (serology Syphilis and HIV serology). The visit ended with a distribution of condoms and possibly drugs.

For the collection of data, a behavioral questionnaire, a follow-up register and a laboratory record were used. The variables studied were: Socio-demographic and behavioral characteristics-Clinical characteristics of the discharges and specimen's laboratory results.

Data were entered and analyzed with the software Epi Info 2000.

\section{Results}

\section{1) Frequency of vaginal discharge}

A total of 911 women consulted, 445 had vaginal discharge, making a frequency of $48.8 \%$ [95\% CI (45.6 - 52.1)].

\section{2) Epidemiological characteristics}

a) Socio-demographic characteristics

The mean age was 28.4 years with extremes of 16 and 54 years. The age group 20 - 29 years represented $47.1 \%$ of the (429/911). According to the marital status, 
singles, divorced and widows accounted for $78.8 \%$ of the population (718/911), Married 17\% (155) and concubines 6.4\% (58). Sex workers accounted for 23.2\% of the population, while occasional prostitution was of the order of $76.8 \%$ of the group. The women out of school and those with primary education accounted for $74.42 \%$ (678/911).

For the distribution according to religion, Catholics accounted for $53.2 \%$ of the population, Muslim $46.3 \%$ and animists $0.5 \%$.

Table 1 (below) gives the distribution of women from the Yèrêlon cohort according to socio-demographic characteristics.

\section{b) Past obstetrical history}

The mean gravity was 2 with extremes of 0 and 15. The mean parity was 2 with extremes of 0 and 10 . Pauciparous accounted for $52.1 \%$ of the population.

c) Contraceptive methods used by women.

There is a diversity of contraceptive methods used by women in the Yèrêlon group.

A contraceptive method was used by $60 \%$ of women (547/911). The proportion of women using condoms alone as a contraceptive method was 43.3\% (395/911). Combined oral contraception was used by $8,7 \%$ of women (79/911) as shown in Table 2.

d) Sexual hygiene

The vaginal douching was practiced by $85.8 \%$ of women (779/911). They were 93.6\% practicing it more than once a day (729/779). Products such as diluted

Table 1. Socio-demographic characteristics of women in the Yèrêlon group.

\begin{tabular}{|c|c|c|}
\hline Characteristics & Numbers & Frequency (\%) \\
\hline \multicolumn{3}{|l|}{ Age (Years) } \\
\hline Less than 20 & 116 & 12.7 \\
\hline $20-29$ & 429 & 47.1 \\
\hline $30-39$ & 265 & 29.1 \\
\hline $40-49$ & 97 & 10.7 \\
\hline More than 49 & 4 & 0.4 \\
\hline \multicolumn{3}{|l|}{ Occupation } \\
\hline Professional sex workers & 211 & 23.2 \\
\hline Occasional sex workers & 700 & 76.8 \\
\hline \multicolumn{3}{|l|}{ Education level } \\
\hline None & 388 & 42.5 \\
\hline Primary & 290 & 31.8 \\
\hline Secondary & 228 & 25.1 \\
\hline Tertiary & 5 & 0.5 \\
\hline Number of women & 911 & 100.0 \\
\hline
\end{tabular}


bleach ( 5 women), potassium permanganate ( 2 women) and lemon juice ( 5 women) were also used for the vaginal douche.

Table 3 below lists the products and Tablets used by women for vaginal douche.

\section{e) HIV serological status}

HIV screening was positive in 350 women, making a frequency of $38.4 \%$. There were 5 cases of HIV 2 and 6 cases of co-infection HIV1 and HIV2.

3) Clinical Features

a) Clinical features of vaginal discharge

The signs associated with vaginal discharge are given in Table 4 below.

Urinary manifestations were made up of pollakiuria or dysuria.

\section{b) Etiologic macroscopic aspects}

Speculum examination revealed macroscopic features suggestive of vaginitis in $83.9 \%(374 / 445)$, cervicitis in $9.8 \%(43 / 445)$, and associated vaginitis to cer-

Table 2. Distribution of women by contraceptive method used.

\begin{tabular}{ccc}
\hline Contraceptive method & Numbers & Frequency (\%) \\
\hline None & 364 & 40.0 \\
COC & 79 & 8.7 \\
Implant & 35 & 3.8 \\
IUD & 8 & 0.9 \\
Male condom & 395 & 43.3 \\
Injectable progestin & 27 & 3.0 \\
Natural methods & 1 & 0.1 \\
Traditional methods & 2 & 0.2 \\
Total & 911 & 100.0 \\
\hline
\end{tabular}

Table 3. Products and solutions used by women in the Yèrêlon group for the vaginal douching.

\begin{tabular}{ccc}
\hline Products and/or solutions used & Numbers & Frequency (\%) \\
\hline Simple water & 465 & 59.7 \\
Perfumed bath soap & 488 & 62.6 \\
Marseille soap & 136 & 17.5 \\
Antiseptics & 48 & 6.2 \\
Others & 28 & 3.6 \\
\hline
\end{tabular}

Table 4. Genital functional signs (366/911).

\begin{tabular}{ccc}
\hline Signs & Numbers & Frequency (\%) \\
\hline Genital itching & 185 & 20.3 \\
Dyspareunia & 139 & 15.3 \\
Urinary symptoms & 42 & 4.6 \\
\hline
\end{tabular}




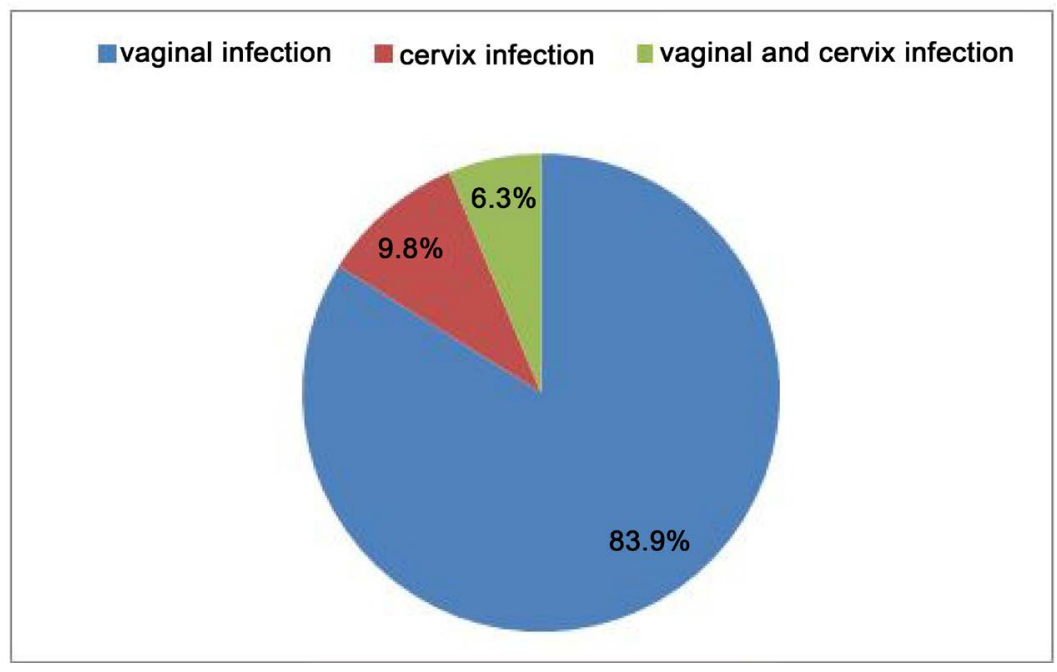

Figure 1. Distribution of vaginal discharge by origin.

vicitis in $6.3 \%$ of cases (28/445) (Figure 1).

\section{4) Biological characteristics}

a) Bacterial vaginosis

Gardenerella vaginalis was found in $41.8 \%$ of cases (381/911).

b) Genital candidiasis

Candida albicans was diagnosed in 7.7\% of cases (70/911).

c) Infection with Trichomonas vaginalis

Trichomonas vaginalis alone was found in $0.8 \%$ of women (7/911).

d) Mixed vaginal infections.

Mixed infections were diagnosed in $7.2 \%$ of women (66/911).

The associations were as follows:

Gardenerella vaginalis and Trichomonas vaginalis in 44 cases;

Gardenerella vaginalis and Candida albicans in 15 cases;

A combination of Candida albicans and Trichomonas vaginalis in 1 case;

And Gardenerella vaginalis, Trichomonas vaginalis and Candida albicans in 6 cases.

The Figure 2 below shows the distribution of vaginitis according to the etiology.

e) Gonorrhea

The 724 endocervical swabs were examined directly and a culture in search of Neisseria gonorrhoeae was found to be negative.

f) Factors associated with vaginal discharge

Table 5 below gives the prevalence of vaginal discharge syndrome (VDS) according to socio-demographic characteristics and women's past medical history.

\section{Discussion}

\section{Epidemiological characteristics of women}

Most studies of sexually transmitted infections show that the majority of patients are between the ages of 20 and 35 [3]-[9]. 
w bacterial vaginosis $₫$ vaginal candidosis $₫$ trichomonas vaginalis $\|$ mixed infections

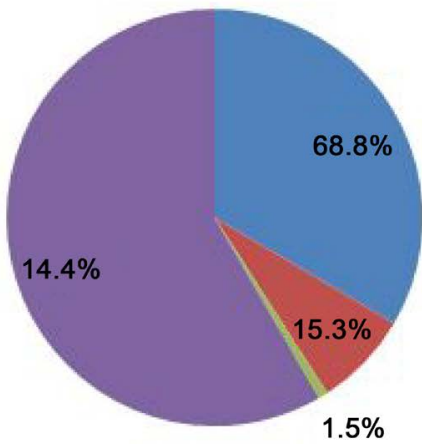

Figure 2. Distribution of vaginitis according to etiology.

Table 5. Prevalence of vaginal discharge syndrome according to socio-demographic characteristics and women's past medical history.

\begin{tabular}{ccccc}
\hline Factors & VDS present & VDS absent & Prevalence of VDS & p \\
\hline Occupation & & & & 0.0078 \\
Professional sex workers & 120 & 91 & 46.9 & \\
Occasional sex workers \& others & 325 & 375 & 46.4 & 0.64 \\
Vaginal douching & & & & \\
Present & 383 & 396 & 59.2 & \\
Absent & 62 & 70 & 5.0621 \\
Male condom & 179 & 216 & 45.3 & \\
Used & 266 & 250 & 51.6 & \\
Non used & & & & \\
COC & 39 & 40 & 49.4 & \\
Used & 406 & 426 & 48.8 & \\
Non used & & & & \\
VIH screening & 199 & 151 & 56.9 & \\
Positive & 246 & 315 & 43.9 & \\
Negative & 445 & 466 & 48.8 & \\
Number of women & & & & \\
\hline
\end{tabular}

VDS: vaginal discharge syndrome.

The mean age in our series was 28.4 years. It is identical to that of Desai [6] in India, which was 28.5 years and superior to those of Wang [10] in China, Cornier [5] in Bulgaria and Reed [11] in Indonesia which were respectively 23.5 years, 23.9 years and 25.8 years.

In terms of educational level, most studies show that the majority of women engaged in sex work (occasional prostitution, or professional sex workers) are out of school or just have the level of primary education [6] [10] [11]. The data 
from our study confirm this trend, where school dropped out and primary school level accounted for $74.3 \%$ the population. They engage in risky behaviors that are rooted in poverty, ignorance and easy gain.

In terms of marital status, the percentages are disparate. Wang [10] in China reported $14 \%$ of singles and $52 \%$ of married or concubines. Reed [11] in Indonesia reported $12 \%$ of singles and $70 \%$ of divorced and Desai [6] in India found $41.7 \%$ of singles and $59.3 \%$ of married.

\section{Frequency of vaginal discharge}

The prevalence of vaginal discharge in our study was $48.8 \%$. Most data from the literature show high frequencies for vaginal discharge in this target population. It was found frequencies of $51.7 \%, 90 \%$ and $94 \%$ respectively in the studies of Desai in India [6], Gaye-Diallo in Senegal [9] and Fonck in Kenya [1].

\section{Prevalence of genital infections}

Many studies on sex workers show a high prevalence of genital infections [1]. Lack of hygiene, promiscuity, non-use of condoms, the existence of genital tract lesions and high-risk practices during sexual intercourse are factors that promote the transmission of STIs and HIV [1] [6] [12] [13].

Our rate of $50.4 \%$ is higher than those of Reed [11] in Indonesia and Wang [10] in China, which were $39 \%$ and $41 \%$ respectively. Higher rates were reported by Nguyen [9] in Vietnam and Fonck [1] in Kenya, which were $75.9 \%$ and 94\%, respectively. Ulcerations in the genital tract increased the risk of HIV infection, and seropositive women developed precancerous cervical lesions more rapidly (CIN2, CIN3) [1].

\section{Etiologies of vaginal discharge}

A variety of germs has been reported by most authors in vaginal discharge [2] [3] [4] [5] [6] [14]. The most frequently encountered germs are Gardenerella vaginalis, Candida albicans and Trichomonas vaginalis [1] [3] [7] [15]. Chlamydia trachomatis and Neisseria gonorrhoeae infections have also been reported [1] [7] [10].

\section{Factors associated with vaginal discharge}

The prevalence of vaginal discharge syndrome was significantly higher in HIVinfected women [p $<0.00013,95 \%$ CI $(1.28$ - 2.21)].

Indeed, the decline in immunity is recognized as a factor favoring opportunistic infections such as genital candidiasis [16] [17].

Authors like Baisley [12] in Tanzani, Fonck [1] in Kenya, Gaye-Diallo [7] in Senegal and Nwadioha [18] in Nigeria reported significantly higher prevalence of bacterial vaginosis in HIV-infected women.

True sex workers had a higher prevalence of vaginal discharge syndrome than occasional sex workers and other women in the population. This difference was statistically significant [ $\mathrm{p}<0.0078,95 \%$ CI $(1.11-2.07)]$.

With relation to age, couple life, condom use or pill use, and the practice of vaginal douching, there was no statistically significant difference. Wang and al noted no association between the practice of vaginal douching and vaginal discharge in sex workers in China. Similarly, Demba [14] and al found no signifi- 
cant difference between the practice of vaginal douching and the occurrence of bacterial vaginosis.

The use of vaginal douching is a relatively widespread practice among sex workers [1] [10] [13]. Different products were used for the genital cleaning (lemon juice, diluted bleach, diluted permanganate, soap, antiseptics). These various products used can disrupt the ecosystem of the vagina with consequences of vaginal irritations and infections. The frequent and regular practice of the vaginal douching represents for these women a means of prevention of the genital infections [19].

Condoms are effective means of fighting STIs and HIV when its use is optimal. Condom users accounted for $43.3 \%$ of the population.

\section{Conclusions}

At the end of this study in the Yèrêlon group of the city Bobo-Dioulasso, the prevalence of vaginal discharge syndrome was $48.8 \%$. The main germs found in vaginal discharge were Gardenerella vaginalis, Candida albicans and Trichomonas vaginalis. Infections were mixed in $14.4 \%$ of cases.

Improving the situation requires preventive measures, diagnosis and management of vaginal discharge in women infected with HIV and sex workers.

\section{References}

[1] Fonck, K., Kidula, N., Jaoko, W., Estambele, B., Claeys, P., Ndinya-Achola, J., et al. (2000) Validity of Vaginal Discharge Algorithm among Pregnant and Non-Pregnant Woman in Nairobi, Kenya. Sexually Transmitted Infections, 76, 33-38. https://doi.org/10.1136/sti.76.1.33

[2] Zimba, T.F., Apalata, T., Sturm, W.A. and Moodley, P. (2011) Aetiology of Sexualy Transmitted Infections in Maputo, Mozambique. Journal of Infection in Developing Countries, 5, 41-47.

[3] Abauleth, R., Boni, S., Kouassi-Mbengue, A., Konan, J. and Deza, S. (2006) Etiologie et prise en charge thérapeutique des leucorrhées infectieuses au CHU de Cocody (Abidjan, Cote d'Ivoire). Cahiers Santé, 16, 191-195.

[4] Baidy, B., Philippon, M., Cunin, P., Meynard, D. and Tandia-Diagana, M. (1997) Etiologie microbienne des écoulements génitaux à Nouakchott, Mauritanie. Virilogie, 1809, 1-3.

[5] Cornier, N., Petrova, E., Cavailler, P., Dentcheva, R., Terris-Prestholt, F., Janin, A., et al. (2010) Optimising the Management of Vaginal Discharge Syndrome in Bulgaria: Cost Effectiveness of four Clinical Algorithms with Risk Assessment. Sexually Transmitted Infections, 86, 303-309.

https://doi.org/10.1136/sti.2009.040832

[6] Desai, V.K., Kosambiya, J.K., Thakor, H.G., Umrigar, D.D., Khandwala, B.R. and Bhuyan, K.K. (2003) Prevalence of Sexually Transmitted Infections and Performance of STI Syndromes against Aetiological Diagnosis, in Female Sex Workers of Red Light Area in Surat, India. Sexually Transmitted Infections, 79, 111-115. https://doi.org/10.1136/sti.79.2.111

[7] Gaye-Diallo, A., NiangDiallo, P.A., Badiane, M., Ndoye, I., Wade, A.S., Diop, I., et al. (2008) Surveillance des infections sexuellement transmissibles au Sénégal: en- 
quête nationale réalisée en 2006 chez 639 femmes enceintes et 605 travailleuses du sexe dans les 11 régions. International Union against Sexually Tansmitted InfectionsAfrica, 3, 6-7.

[8] Mahmoudi, R.M., Zafarghandi, S., Abbasabadi, B. and Tavallaee, M. (2011) The Epidemiology of Candida Species Associated with Vulvovaginal Candidiasis in an Iranian Patient Population. European Journal of Obstetrics, Gynecology, and Reproductive Biology, 155, 199-203. https://doi.org/10.1016/j.ejogrb.2010.11.022

[9] Nguyen, T.V., Khuu, N.V., Thi Le, T.T., Nguyen, A.P., Cao, V., Tham, D.C., et al. (2008) Sexually Transmitted and Risk Factors for Gonorrhea and Chlamydia in Female Sex Workers in SocTrang, Vietnam. Sexually Transmitted Diseases, 35, 935940. https://doi.org/10.1097/OLQ.0b013e3181812d03

[10] Wang, B.O., Li, X.M., Stanton, B., Yang, H., Fang, X., Zhao, R., et al. (2005) Vaginal Douching, Condom Use, and Sexually Transmitted Infections among Chinese Female Sex Workers. Sexually Transmitted Diseases, 32, 696-702.

https://doi.org/10.1097/01.olq.0000175403.68410.ec

[11] Reed, B.D., Ford, K. and Wirawa, D.N. (2001) The Bali STD/AIDS Study: Association between Vaginal Hygiene Practices and STD among Sex Workers. Sexually Transmitted Infections, 77, 46-52. https://doi.org/10.1136/sti.77.1.46

[12] Baisley, K., Changalucha, J., Weiss, H.A., Mugeye, K., Everett, D., Hambleton, I., et al. (2009) Bacterial Vaginosis in Female Facility Workers in North-Western Tanzania: Prevalence and Risk Factors. Sexually Transmitted Infections, 85, 370-375. https://doi.org/10.1136/sti.2008.035543

[13] Imade, G., Sagay, A., Egah, D., Onwuliri, V., Grigg, M., Egbodo, C., et al. (2008) Prevalence of HIV and Other Sexually Transmissible Infections in Relation to Lemon or Lime Juice Douching among Female Sex Workers in Jos, Nageria. Sex Health, 5, 55-60. https://doi.org/10.1071/SH07047

[14] Demba, E., Morison, L., van der Loeff, M.S., Awasana, A.A., Gooding, E., Bailey, R., et al. (2005) Bacteria Vaginosis, Vaginal Flora Patterns and Vaginal Hygiene Practices in Patients Presenting with Vaginal Discharge Syndrome in the Gambia, West Africa. BMC Infectious Diseases, 5, 1-12. https://doi.org/10.1186/1471-2334-5-12

[15] Varsha, C., Ved, P., Kiran, A., Vijender, K.A., Arun, S. and Sachin, P. (2012) Clinico-Microbiological Profile of Women with Vaginal Discharge in a Tertiary Care Hospital of Northern India. International Journal of Medical Science and Public Health, 1, 75-80. https://doi.org/10.5455/ijmsph.2012.1.75-80

[16] Casari, E., Ferrario, A., Morenghi, E. and Montanelli, A. (2010) Gardnerella, Trichomonas vaginalis, Candida, Chlamydia trachomatis, Mycoplasma hominis and Ureaplasma urealyticum in the Genital Discharge of Symptomatic Fertile and Asymptomatic Infertile Women. New Microbiologica, 33, 69-76.

[17] Ray, A., Ray, S. and George, A.T. (2011) Swaminathan n. Interventions for Prevention and Treatment of Vulvovaginal Candidiasis in Women with HIV Infection. The Cochrane Database of Systematic Reviews, 10, 8739.

[18] Nwadioha, S., Egah, D., Banwat, E., Egesie, J. and Onwuezobe, I. (2011) Prevalence of Bacterial Vaginosis and Its Risk Factors in HIV/ AIDS Patients with Abnormal Vaginal Discharge. Asian Pacific Journal of Tropical Medicine, 4, 156-158. https://doi.org/10.1016/S1995-7645(11)60059-X

[19] Rosenberg, M.J., Phillips, R.S. and Holmes, M.D. (1991) Vaginal Douching. Who and Why? The Journal of Reproductive Medicine, 10, 753-758. 
Submit or recommend next manuscript to SCIRP and we will provide best service for you:

Accepting pre-submission inquiries through Email, Facebook, LinkedIn, Twitter, etc. A wide selection of journals (inclusive of 9 subjects, more than 200 journals)

Providing 24-hour high-quality service

User-friendly online submission system

Fair and swift peer-review system

Efficient typesetting and proofreading procedure

Display of the result of downloads and visits, as well as the number of cited articles Maximum dissemination of your research work

Submit your manuscript at: http://papersubmission.scirp.org/

Or contact ojog@scirp.org 